\title{
La visualidad de las galerías urbanas a través de un cuento de Julio Cortázar
}

Maria A. Taboza

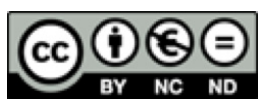

Esta obra está bajo una licencia Creative Commons

Reconocimiento-No comercial-Sin Obra Derivada 
Artículos

\title{
La visualidad de las galerías urbanas a través de un cuento de Julio Cortázar
}

\author{
Maria A. Taboza \\ Universidad Laval, Canadá \\ maria-aparecida.taboza.1@ulaval.ca
}

Recibido: 28 de setiembre de 2016 Aprobado: 28 de octubre de 2016

\section{Resumen}

Para dar a conocer los misterios de la ciudad, en la obra de Julio Cortázar, se analiza el cuento "El otro cielo" (Todos los fuegos el fuego, 1982), en el que la galería arquitectónica (o el paseo urbano) constituyen para el paseante un dispositivo de la visualidad. Nuestro objetivo es discutir acerca del tipo de visualidad que esta infraestructura arquitectónica (inventada en el siglo XIX pero que persiste, hasta nuestros días, en el contexto de las ciudades modernas) instaura en el relato de Cortázar. Los escritos de Walter Benjamin sobre la ciudad de París en el siglo XIX iluminan la discusión.

Palabras clave: ciudad; visualidad; pasajes urbanos; Julio Cortázar; Walter Benjamin

\begin{abstract}
To unveil a city mystery place in the work of Julio Cortázar, we analyze the short story "The other sky" (All fires the fire, 1982) regarding the gallery (or passage) as apparatus of visuality. Our aim is to discuss what kind of visuality this construction (invented in the nineteenth century and which traces persist to this day in modern cities) establish in the short story. The writings of Walter Benjamin about the city of Paris in the nineteenth century illuminate the discussion.
\end{abstract}

Keywords: city; visuality; passages; Julio Cortázar; Walter Benjamin 
Le ciel nous découpe sur son passage. Prend des reliefs insoupçonnés lorsqu'il se casse dans nos mains. [El cielo nos corta en su pasaje. Toma relieves insospechados cuando se rompe en nuestras manos] (Duval, 2014, p. 60).

En la obra del escritor argentino Julio Cortázar, la ciudad es omnipresente. Con sus múltiples direcciones y sentidos, calles, avenidas, bulevares, autopistas, subterráneos, la ciudad es viva y en constante cambio en su obra. En Buenos Aires, la 591 de la Avenida de Mayo, una vía de inspiración haussmannienne, encontramos el café London City, frecuentado por Cortázar cuando escribía su primera novela, Los premios. Después de trasladarse a París en 1951, Cortázar continúa siendo el hombre que mira a la multitud a través de las ventanas de un café, después de haber aprendido la lección con Poe, Rimbaud, Baudelaire, entre otros.

Para conocer y reconocer la ciudad extranjera, hay que ir a pie, perderse y encontrarse en sus barrios. Es a través de la flânerie (el paseo ocioso) que la ciudad se revela en sus lugares claros y en los sombríos, en los estratos temporales que conviven mutuamente. Es posible reconstruir una cierta mirada, una perspectiva de las áreas urbanas de Buenos Aires y París, siguiendo los pasos de los personajes de Cortázar, trazando un recorrido no lineal entre estas dos metrópolis. Buenos Aires se ve desde París, mientras que París es vista a través de los ojos de un escritor sudamericano, que pone de relieve la dinámica de la mirada desde el discurso latinoamericano, en palabras de Silviano Santiago ${ }^{1}$.

La ciudad es también el lugar de misterio, con ventanas, puertas, puentes y pasajes. Considerados por el escritor como eso que da el ritmo a una ciudad, estos espacios mágicos se pueden convertir en los umbrales de transposición de la realidad aparente, rompiendo con la rutina automatizada, en el que sus vínculos se tejen en direcciones imperceptibles. Para dar a conocer uno de esos lugares misteriosos de la ciudad de Cortázar, se analiza el cuento "El otro cielo" (incluido en el volumen Todos los fuegos el fuego, 1982), que da cuenta de la galería (o el pasaje arquitectónico o urbano) como dispositivo de visualidad. Nuestro objetivo es discutir a qué tipo de visualidad responde esta construcción, inventada en el siglo XIX, que ha dejado huella hasta nuestros días en las ciudades modernas, presente en la narrativa contemporánea.

${ }^{1}$ El concepto de "entre-lugar" permite analizar el discurso del escritor latinoamericano como un espacio de enunciación, en vez de un lugar de la copia, de la transgresión de los modelos impuestos por una cultura hegemónica basada en la colonización europea. "Entre-lugar" no es de acá ni de allá, es una atmósfera de observación, análisis, interpretación y transgresión, que desplaza las nociones de unidad, de pureza y de autenticidad atribuidas a la cultura europea (Santiago, 2000). 
El desarrollo de las galerías en toda Europa (y en América) está vinculado a los progresos técnicos de los metales y del vidrio. Vitrinas cada vez más grandes, con luz natural durante del día e iluminación artificial por la noche, la galería es un dispositivo visual complejo, que permite la reunión de los diferentes elementos, a veces contradictorios, de la modernidad, como lo veremos más adelante en este artículo.

\section{Una patria secreta dentro de la cuidad}

En el cuento "El otro cielo", el narrador-protagonista, anónimo, cuenta su propia historia en diferentes épocas: en el presente, vive con su madre, trabaja en la Bolsa y está comprometido con Irma en la Argentina de 1940; en el pasado reciente, sus recuerdos de la adolescencia, cuando desarrolló un gusto por la flânerie por las calles de Buenos Aires, sobre todo en sus galerías; y en un pasado aún anterior, durante el cual también trabaja en la Bolsa y vive una peligrosa historia de amor a través de las galerías de París de la década de 1870. Sin embargo, ya que se trata de una narración cortazariana, ni las épocas ni los espacios están claramente delimitados.

En la actualidad, en la vida de todos los días, el narrador es lo que se llamaría un ciudadano de la clase media argentina de la época. El trabajo, la familia y el matrimonio a futuro son símbolos de una vida mecánica y previsible, definida por convenciones sociales. Al parecer, el protagonista los acepta. Sin embargo, en su subjetividad, él escapa de las reglas. El hecho de caminar por las calles sin tener un propósito, sin fijarse en el reloj, representa para él la libertad de la memoria y el afecto.

...bastaba ingresar en la deriva placentera del ciudadano que se dejaba llevar por sus preferencias callejeras, y casi siempre mi paseo terminaba en el barrio de las galerías cubiertas, quizá porque los pasajes y las galerías han sido mi patria secreta desde siempre (Cortázar, 1982, pp. 135).

Su principal refugio, donde se siente fuera del tiempo y del espacio, es el Pasaje Güemes. Como en un sueño, este pasaje en Buenos Aires ofrece la atmósfera al protagonista que le permite transportarse a las galerías parisinas del siglo XIX, sobre todo a la Galerie Vivienne. En un instante, el va y viene de un espacio-tiempo a otro y vive un sinnúmero de aventuras.

Me asomaba con la falsa indiferencia a las puertas del pasaje donde empezaba el último misterio ... Todavía hoy me cuesta cruzar el Pasaje Güemes sin enternecerme irónicamente con el recuerdo de la adolescencia al borde de la caída: la antigua fascinación perdura siempre ... La Galerie Vivienne, por ejemplo, o el Passage des Panoramas con sus ramificaciones, ...ese mundo que ha optado por un cielo más próximo, de vidrios sucios ... cuánto de ese barrio ha sido mío desde siempre (Cortázar, 1982, pp. 136-137). 
Es, por lo tanto, en las galerías y sus ramificaciones laberínticas que el narrador encuentra su patria fuera del espacio-tiempo, fuera de las obligaciones de las rutinas. La transición de un espacio-tiempo a otro se produce sin extrañeza por el personaje, ya que este tiene lugar dentro de su universo subjetivo y conocido.

En París, en la Galerie Vivienne, se enamora de Josiane, una prostituta. Con ella y otros compañeros típicos de la época, los bohemios, viaja a la ciudad, a las galerías cubiertas, cafés, teatros; juntos, se divierten, disfrutando del vino, de la amistad, de los placeres urbanos. Sin embargo, este paraíso recuperado (el mítico París de los sueños y la diversión, la ciudad del amor y la orgía) se convierte de repente en un infierno. Un asesino en serie acecha el área y ataca a las prostitutas en las oscuras calles de París en el siglo XIX. Así, la ficción abre sus puertas al miedo y al terror en las ciudades modernas, como lo destaca Leila Perrone-Moisés.

La ciudad es el escenario de varios crímenes, el criminal y la policía son personajes muy presentes. No es casualidad que la novela negra fue inventada en 1840 por Edgar Allan Poe. Walter Benjamin ha estado atento a este aspecto agresor de la ciudad moderna (Perrone-Moisés, 2004, p. 104).

Un punto de quiebre en el cuento, simbolizado por una escena en la que un criminal muere en la guillotina, marca el momento en que el narrador comienza a perder su paraíso secreto. Se llega a un callejón sin salida en relación al contexto de cada época: en el pasado, él vive las consecuencias de la delincuencia urbana, del sistema de justicia que se impone con la guillotina, de la marginación de ciertos sectores de la sociedad, y de las penurias de la guerra franco-prusiana; en el presente, él vive la instrumentalización de la vida por el capitalismo, el desencanto burgués, la tensión del final de la Segunda Guerra Mundial, la bomba de Hiroshima, los sistemas políticos opresivos que llegan a América Latina.

A pesar de que Cortázar no leyó los extractos de Livre de Passages, de Walter Benjamin, el escritor argentino parece poner en evidencia dentro del cuento imágenes oníricas del pasado. La superposición de períodos muestra que, en un sentido, el siglo XX ya estaba en el vientre del XIX, y que las promesas de progreso de la tecnología y el capitalismo resultarían falsas.

El método de Benjamin corresponde de forma sorprendente con el método de Cortazar en "El otro cielo". La mirada que se lanza sobre el pasado está informada del futuro de ese pasado; al mismo tiempo, él está en condición de comprender su presente a la luz de eso que se anunciaba (eso que se preparaba) del interior del pasado. Ese pasado recibido como un futuro anterior (Perrone-Moisés, 2004, p. 102).

Para entender la relación entre lo antiguo y lo nuevo -que no son mutuamente excluyentes, sino que se superponen, como en el cuento- Benjamin propone un método original del 
conocimiento de la historia. Este método consiste en "cruzar el pasado con la intensidad de un sueño, para experimentar el presente como el mundo de la vigilia a la que se refiere el sueño" (citado en Perrone-Moisés, 2004, p. 101). De este modo, el sueño y el inconsciente, como los surrealistas lo habían preconizado, se convierten en una forma de conocimiento. Sin embargo, hay que despertarse para llevar las imágenes oníricas a un nivel de legibilidad, haciendo visibles las imágenes del pasado dentro del presente.

Según Benjamin, en el momento donde el otro tiempo y el ahora se reúnen, se crea la imagen dialéctica, la cual contiene las contradicciones de un pasado que sueña la generación siguiente y de un presente que busca la novedad, la modernidad, dentro del pasado, pero sin aportar lo nuevo. En este sentido, el cuento de Cortázar presenta algunas imágenes dialécticas de la modernidad, como el narrador y su doble (el extranjero, el inmigrante), el extranjero y el criminal, la ciudad de París y de Buenos Aires, las galerías europeas y latinoamericanas, el flâneur y el hombre de negocios, la prostituta y la novia, los personajes en contra de la ley y la familia burguesa, la guerra franco-prusiana y la Segunda Guerra Mundial, la Ciudad de la Luz y la Ciudad de las Sombras.

\section{Un umbral de tiempo en la ciudad}

Según el relato de "El otro cielo", entrar en una galería significa estar fuera del tiempo y, a la vez, ser transportado a otra época, en el París del siglo XIX, donde este tipo de construcción es concebida, conociendo su período de gloria. Como si tuvieran un alma, las galerías permanecen como lugares donde es posible encontrar algo de magia en la ciudad y de vivir la nostalgia de una época distante, pero siempre presente.

El modelo arquitectónico de la galería existe desde 1780 en Francia. En los jardines del Palais-Royal, las Galeries de Bois y, más tarde, la Galerie Vitrée ofrecería a los parisinos un paseo de negocios y de placer. Era el lugar de moda de París, visitado también por los provincianos y los extranjeros. Como destaca Patrice Moncan, estas galerías "llevan con ellas cualquier cosa que edificará el espíritu de los pasajes cubiertos de París, y les servirán a la vez de proyectos y de modelos" (Moncan, 1995, p. 92).

Como Walter Benjamin destaca, en su obra París: capital del siglo XIX², la galería es un espacio privado hecho público según los intereses especulativos de sus propietarios. Si bien en principio era un acceso directo, una suerte de atajo, rápidamente las tecnologías del siglo XIX, como

${ }^{2}$ En el libro, el autor utiliza el término "pasaje" como sinónimo de "galería”. En Inglaterra, estas construcciones son también conocidas como arcadas. 
el trabajo en hierro y en vidrio, permitieron la erección de techos tan prácticos como imponentes. Gracias a esta nueva construcción, el parisino puede caminar con comodidad, protegido de la intemperie y disfrutar de la luz natural, que pasa a través de las ventanas, y de la iluminación de gas durante la noche, lo que le da la seguridad en comparación con las oscuras calles de la ciudad.

Esto explica el gran éxito de las galerías, que se multiplican en toda Europa y se convierten rápidamente en lugares de gran agitación social y cultural. Pero además, el descubrimiento de su potencial comercial completa la fascinación hacia estas estructuras. Las galerías están desbordadas de tiendas de lujo que exponen en sus mejores vitrinas las novedades de la industria y productos de diferentes rincones del mundo. Patrice Moncan, haciendo eco a Benjamin sobre el concepto de galería, afirma:

Si hay que encontrar una influencia del concepto de pasaje, no es dentro de un modo arquitectural que hay que buscar, pero si dentro de un sistema económico: el capitalismo. El pasaje es, en efecto, unos de los primeros infantes del capitalismo inicial. Él es, a la vez, el fruto de la especulación inmobiliaria y de la Revolución Industrial que producía bienes de consumación en serie. Los pasajes fueron los primeros distribuidores de ese lujo nuevo: el lujo industrial (Moncan, 1995, p. 41).

Por lo tanto, las galerías son un lugar de convergencia de los principios del capitalismo en desarrollo: los vendedores y consumidores de una nueva forma de vida y mirada. Se debe atraer la atención del público por las vitrinas, los objetos, las novedades del mundo que circulan en este espacio privilegiado de la visualidad. Por ejemplo, a finales del siglo XIX, surgieron las vitrinas con lupas con el fin de dar realce a las mercaderías exhibidas. Por otra parte, había en las galerías salones de belleza que permitían a los transeúntes peinarse y asearse para continuar su paseo. Consecuentemente, es un lugar para ver y ser visto, un circuito de exhibicionismo y espectáculo. Al describir la galería, Eduard Kolloff hace hincapié en este aspecto de la atracción de los peatones en movimiento temporal mientras se proporciona la seguridad y el placer, dos preocupaciones crecientes de la modernidad:

No era suficiente de eliminar los peligros y las ansiedades del paseante de la calle concurrida, era necesario atraerle, de tal manera que una vez que había puesto un pie en el pasaje traicionero, este se siente atrapado en un círculo mágico, olvidando todo lo demás. ... Se proporciona el pasaje con dos filas de boutiques abiertas, dónde la mercancía y la mujer del comerciante, ambas atractivas, arrebataban la mirada (Kolloff citado par Moncan, 1995, p. 11)3.

\footnotetext{
${ }^{3}$ Un siglo después de las palabras escritas en 1839 por Kolloff, nos encontramos en la página web de la Galerie Vivienne, la siguiente invitación: "Venid a pasear por un momento fuera de tiempo, un marco excepcional". Consultar: <galerie-vivienne.com>.
} 
En última instancia, las galerías se han convertido en espacios de esparcimiento multifuncionales (con alojamiento, cafés, restaurantes, librerías, tiendas de moda, salas de juegos, teatros, prostitución, etc.). Algunas de las más famosas galerías parisinas de la época son mencionadas dentro del cuento de Cortázar, como Passage des Petits-Pères (1777), Passage du Caire (1798), Passage des Panoramas (1799), Galerie Sainte-Foy (1813), Galerie Vivienne (1826), Galerie Colbert (1826), Passage Verdeau (1846), Passage des Princes (1860). En comparación con las formas de visualidad que se presentan mediante la circulación por estos lugares, subrayamos el gran éxito del Passage des Panoramas desde su aparición. "Dentro de los panoramas, la ciudad se ensancha en forma de paisaje, como lo hará más adelante, de manera más sutil, por el flâneur" (Benjamin, 1971, p. 123). En confluencia con varias otras prácticas y dispositivos (como la linterna mágica, el tableau vivant, el teatro de la imagen, la magia, etc.), las panorámicas tienen un rol esencial en la cultura visual del siglo XIX.

De hecho, el narrador de la historia analizada cae bajo el hechizo de la galería arquitectónica. Él es seducido por ella y se convierte en dependiente de los placeres, visuales, que esta ofrece. Pero como buen jugador de la Bolsa, opta por tomar riesgos y se aventura en sus corredores, contra la falsa promesa de la modernidad que le da una vida segura y automatizada.

El núcleo de esta historia parisina ocurre en las galerías, sobre todo en el Palais-Royal y los grandes bulevares. Sin embargo, la preferencia del narrador se localiza en la Galerie Vivienne, su puerta de entrada al siglo XIX. Situada entre el Palais-Royal y el edificio de la Bolsa de Valores, la Galerie Vivienne fue inaugurada en 1826 con la pretensión de ser la más elegante de París. El arquitecto François-Jacques Delannoy utiliza "varios símbolos de éxito (coronas de laurel, hojas de trigo y palmas), riqueza (cuernos de la abundancia) y el comercio (caduceo de Mercurio)" (Moncan, 1995, p. 146), para ilustrar su importancia. El éxito de esta galería fue inmediato y pronto se convirtió en la más popular de la capital francesa.

No es una casualidad que la figura de Mercurio sea representada en las galerías. Dios del comercio, de los viajes y mensajero en la mitología romana, constituye el protector de la Bolsa de Valores (el corazón del sistema capitalista y la especulación financiera), su nombre está vinculado a las palabras latinas merx (mercancía), mercari (comercio) y merces (salario). No hay que olvidar que el narrador trabaja en la Bolsa en los siglos, ya que es "la institución que no solo 
resiste el paso del tiempo, pero que, cada vez más, controla los caminos de la historia", analiza Leila Perrone-Moisés (2004, p. 109) ${ }^{4}$

Bajo otro cielo, en América del Sur del siglo XX, el Pasaje Güemes fascina al narrador y es el portal de viajes en el tiempo. Construido entre 1912 y 1915, su arquitectura se inspira en las grandes galerías extranjeras del momento. Esta es la primera galería y el primer rascacielos de América del Sur, con sus 87 metros de altura y catorce plantas. Situado entre la calle Florida (una de las calles más concurridas de la ciudad) y San Martín, este edificio-pasaje representaba la modernización de la capital de Argentina. Por ejemplo, los ascensores tenían una velocidad prodigiosa hasta el momento, porque viajaban 140 metros de altura en 60 segundos. En la planta superior del edificio había un telescopio, de manera que el público tenía acceso a una vista panorámica de la ciudad.

Sin embargo, en los años 1940, la época en que el narrador frecuentó la Galería Güemes, esta vivió su decadencia, como la padecían las galerías europeas ${ }^{5}$. Esta se convierte en un escenario ideal para los personajes marginales y las prácticas ilegales

el Pasaje Güemes, territorio ambiguo donde ya hace tanto tiempo fui a quitarme la infancia como un traje usado. Hacia el año veintiocho, el Pasaje Güemes era la caverna del tesoro en que deliciosamente se mezclaban la entrevisión del pecado y las pastillas de menta, donde se voceaban las ediciones vespertinas con crímenes a toda página y ardían las luces de la sala del subsuelo donde pasaban inalcanzables películas realistas (Cortázar, 1982, p. 136).

Según una lectura benjaminiana, el Pasaje Güemes sería un doble retraso de la Galerie Vivienne. Del mismo modo, la historia oficial de América Latina constituiría una fantasmagoría de la historia europea, imitando los modelos de progreso (y desastres) de los mismos ${ }^{6}$. En resumen, dentro del cuento, la galería corresponde a un lugar de contradicciones y ambigüedades, donde convergen diferentes épocas, cada una de las cuales ayuda a revelar la cara oculta de la otra.

\footnotetext{
${ }^{4}$ Consultar Christophe Reffait (2007), La Bourse dans le roman du second XIXe siècle. Discours romanesque et imaginaire social de la spéculation, donde el autor analiza la representación de la Banca dentro de la literatura de Alexandre Dumas, Émile Zola, Proudhon, entre otros, y la aparición del especulador. ${ }^{5}$ Durante todo el siglo XIX, bajo el impulso de la destrucción creadora de la modernidad, según expresión de Joseph Schumpeter, numerosas galerías fueron construidas y destruidas a lo largo de toda Europa. Véase el apéndice de este artículo una ilustración de pasajes que existen en la región de París, donde se desarrolla el cuentos de Cortázar.

6 "París, durante el siglo XIX y la primera parte del siglo XX fue, para los sudamericanos, el modelo de la civilización de lujo. Dentro del imaginario latinoamericano, París era la ciudad de los placeres prohibidos, de la bohème, de las mujeres fáciles y fatales" (Perrone-Moisés, 2004, p. 106).
} 


\section{Los personajes de la galería: el flâneur y la prostituta}

En el libro Les passages couverts de Paris (1995), Patrice de Moncan enumera una serie de personajes típicos: los pobres, los estafadores, el flâneur, los jugadores y los especuladores, las prostitutas, las multitudes, los extraños, etc. En el cuento de Cortázar, dos buenos ejemplos de los personajes marginados en el siglo XIX, el flâneur y su musa, la prostituta Josiane, están en el corazón de la historia.

De hecho, la flânerie en las calles y galerías marca una nueva forma de ver la ciudad, permitiendo la creación de toda una poética que tiene eco en la literatura (Rimbaud, Baudelaire, Aragón, Lautréamont, etc.) y en las artes visuales. Inscrito en esta tradición, Cortázar busca su propia definición del flâneur, lo que significa realmente sería el caminar y perderse en una ciudad. En la película Instrucciones para visitar a Julio Cortázar (1978), de Erik Van Zuylen, el escritor dice que ve la ciudad como una especie de poema anónimo y, después de un paseo, se va a casa con un cuadro bajo el brazo, hecho de signos, sonidos, olores y de indicaciones que ofrece la ciudad.

Por ejemplo, ante una pared cubierta con carteles, él dice que no observa el más reciente, sino los que están pegados debajo de este. En otras palabras, se trata de ver a través de las capas del tiempo los aspectos ocultos de la ciudad. Y para lograr eso, adopta una mirada curiosa, una actitud de gato cazador. "Temeroso y exaltado, el viajero entra en la ciudad como un gato en un territorio extranjero. Como un gato, él se lanza a la aventura y a la deriva donde todo es nuevo, donde todo es diferente" (Cortázar, 1981, p. 1). En Le Peintre de la vie moderne, Baudelaire hace una metáfora de la mirada que vuelta hacia la novedad por medio del convaleciente y el infante: "El convaleciente aprovecha en un alto nivel, como el infante, de la facultad de interesarse de una forma vivaz sobre las cosas, aún de las más triviales en apariencia. ...El niño observa todo como una novedad" (Baudelaire, 1951, pp. 879-880).

Es el gesto de la flânerie el que permite al narrador del cuento penetrar en los misterios y las capas del tiempo de Buenos Aires a París y de un siglo al otro. Según Benjamin, es precisamente la mirada del flâneur la que agrandará la ciudad.

El otro personaje clave de la historia corresponde a la prostituta Josiane. Como André Breton a la búsqueda de Nadja por las calles de París, o como Baudelaire que observa la mujer en tanto que fuente de placer y de dolor ${ }^{7}$, el narrador sigue el rastro de Josiane dentro de las

\footnotetext{
${ }^{7}$ Los poemas de Baudelaire contienen una ambigüedad con respecto a la mujer y el amor. Ve la mujer como la deriva "de los placeres y los dolores más molestos y fecundos" (Baudelaire, 1951, pp. 901-902).
} 
galerías parisinas. Evidentemente, ocurre una fusión entre la ciudad (representada por la galería) y la mujer prostituida, las dos fuentes de placer y obsesión del narrador.

Otra cosa nos acercó, y también en eso fui afortunado, porque a Josiane le gustaban las galerías cubiertas, quizá por vivir en una de ellas ... Su habitación, por ejemplo, la bohardilla pequeña y limpia que para mí no había tenido otra realidad que la de formar parte de la galería (Cortázar, 1982, p. 139-140).

Efectivamente, el enlace entre la prostitución y las galerías tiene su origen en los jardines del Palais-Royal, dentro de las Galeries de Bois. Y eso porque la galería ofrece el espacio ideal para el rencuentro entre los negocios y los placeres mundanos, con sus salones de juego, sus lugares de especulación financiera, de turismo y de comercio. Una estadística de 1831, por ejemplo, ha registrado 3.248 prostitutas inscritas oficialmente en París, dejando de lado la prostitución clandestina. Indudablemente, las galerías y los bulevares convocan un gran número de consumidores de la prostitución.

Como lo revela Benjamin, los pasajes son al mismo tiempo casa y calle, y la prostituta es a la vez vendedora y mercancía. Relegada al silencio en el relato, como la madre y la novia, la amante y la prostituta Josiane encarna la condición femenina de explotación en el siglo XIX (eso que no cambió en el transcurso del siglo XX): la persecución, la fuga, el miedo a ser asesinada, las falsas promesas de libertad. En tanto que expositora y demostradora dentro de las galerías, ella simboliza muy bien el fetichismo de la mercadería y las contradicciones de la modernidad ${ }^{8}$.

\section{Sombras y luces: la visualidad a través del vidrio}

Dentro del cuento "El otro cielo", si consideramos las numerosas diferencias entre los dos siglos, la iluminación constituye un elemento fundamental. Sobre todo, hay que imaginar como la luz artificial se refleja en la ciudad de París al fin del siglo XIX. Eso influenció las formas de visualidad que se instauraron en la época. Esta iluminación se realizaba, sobre todo, con bujías o, dentro de ciertos lugares, con las lámparas de gas. El objetivo de la industria era de mejorar el color y la calidad de la luz obtenida a través del vidrio, con el fin de crear el efecto de una visión semejante a la del pleno día ${ }^{9}$. Ciertamente, este potencial de las galerías de hacer

\footnotetext{
${ }^{8}$ Literalmente, dentro de ciertas ciudades actuales como Amsterdam, Anvers y Bruselas, hay prostitutas expuestas en vitrinas. El cliente puede verlas a través estos dispositivos y seleccionar a su gusto. En este sentido, el documental Le commerce du sexe (2014), de Ève Lamont, muestra el horror de la industria de la prostitución en Quebec.

${ }^{9}$ Concerniente a la materialidad de la iluminación, señalamos que antes de la invención del aire comprimido, el vidrio de las lámparas de gas tenía la talla del soplo bucal.
} 
entrar la luz del sol durante el día, así como de distribuir la iluminación artificial durante la noche, transformó las maneras de ver.

El primer momento donde las miradas de los dos personajes se cruzan sucede en el contexto de la Galerie Vivienne, "bajo las figuras de yeso que el pico de gas llenaba de temblores (las guirnaldas iban y venían entre los dedos de la Musas polvorientas)" (Cortázar, 1982, p. 138). Desde entonces se muestra la importancia de la mirada bajo la incidencia de la luz artificial de la época.

"Los pasajes constituyen el primer lugar donde la gente viene para admirar la iluminación de gas", escribe Benjamin (1971, p. 134) haciendo alusión al éxito de estos espacios. Este sistema de iluminación, que revolucionó la vida en París en el siglo XIX, antes de que llegara la electricidad, permite que las personas tengan una vida nocturna, especialmente para ver los espectáculos. En comparación con la calles rectas y oscuras, las galerías se dejan penetrar por la luz del día y se iluminan por la noche aumentando la seguridad de los peatones ${ }^{10}$. Esta es la transfiguración de la ciudad como un sueño mágico.

Cuando, en 1811, aparecen las primeras luces de gas en el Pasaje de los Panoramas, París, se ilumina aún por las velas y lámparas de aceite. Los paisajes, de cierta forma, continuam brillando co un fuego hasta ahora desconocido, contrastando fuertemente con las calles oscuras. ... Los pasajes cubiertos atraen a los parisimos durante la noche, como una lámpara que atrae a las mariposas (Moncan, 1995, pp. 18-19) ${ }^{11}$.

Por esta razón, el narrador del cuento, sobre todo, camina por las galerías durante la noche, el instante mágico cuando la iluminación se enciende y también un espacio propicio de rencuentro con Josiane: "A cada momento me ganaba el deseo de volver; frente a las pizarras de los diarios, con los amigos, en el patio de casa, sobre todo al anochecer, a la hora en que allá empezarían a encenderse los picos de gas" (Cortázar, 1982, p. 155).

Observamos la incidencia de la luz en la construcción de la narración dentro de varias escenas: bajo la sombra de las galerías, el narrador ve la silueta de Josiane; él la acompaña en la escalera de caracol en su habitación porque ella tiene miedo de que la vela se apague; los

\footnotetext{
${ }^{10}$ Mientras que las ciudades modernas son cada vez más seguras (al menos en sus centros), la noción de inseguridad está en el centro de las preocupaciones de Occidente del siglo XX. En cierto modo, esto está relacionado con el desarrollo de los medios de comunicación y el discurso de amenza inminente de las identidades nacionales en relación con la alteridad.

${ }^{11}$ En 1840, la Opera Garnier tenía más quemadores de gas que toda la ciudad de París. La iluminación eléctrica apareció en las calles de la capital en 1857, pero de manera más sistemática para sustituir el alumbrado de gas en 1877.
} 
contrastes de luces y sombras entre el público que observa la escena de decapitación tienen un fuerte impacto en la impresión de la violencia que emana de ella. En resumen, un juego de luz, casi cinematográfico, impregna la historia.

En comparación con el título del cuento ("El otro cielo"), el autor se refiere al cielo de cristal de las galerías. Un cielo más cercano, casi tangible y humano, pero artificial, como todos los inventos mecánicos (y pronto eléctricos) de la modernidad. El narrador contrasta los espacios abiertos (las calles exteriores) y los espacios cerrados (las galerías), siendo estos últimos elegidos por él como un territorio íntimo, donde es capaz de viajar hacia su propio universo. El cielo de las ciudades de Buenos Aires y París se superponen al cielo de vidrio de las galerías, dentro de las cuales el autor manipula el espacio y el tiempo, pasando de una época y de una ciudad a la otra, como el cielo de un diaporama de Daguerre, el cual pasa de la oscuridad a la claridad, de los efectos de la luna a los del sol.

Al igual que la metodología historiográfica de Benjamin, atravesar la galería como umbral nos permite observar las luces de la reciente ciudad moderna (mítica e inspiradora de nostalgia), pero también las sombras de las barbaries que se avecinan en el siglo XX. Según este pensador, en el siglo XIX, no sabemos construir por medio del vidrio o el hierro. Por lo tanto, la luz que pasa a través de la cubierta de cristal se encuentra sucia y nublada, como en las fotografías de Charles Marville.

En este sentido, la galería no es un dispositivo de visualización de la luz transparente, pero sí de opacidad de los procesos históricos y culturales, a menudo ocultos bajo el signo del progreso capitalista. Es por medio de esta luz opaca que la narrativa de Cortázar establece una denuncia de la instrumentalización de la vida moderna, la especulación financiera, la marginación de ciertos grupos sociales, de los cuales forman parte la prostituta y el inmigrante, conjuntamente con la delincuencia en las grandes ciudades. Pero tal vez la violencia más grave es la que comete el Estado, bajo el nombre de la justicia y de la guerra.

Con el fin de generar una reflexión, la galería se transforma en un dispositivo complejo. Como innovación arquitectónica del siglo XX, esta acoge muy bien los valores de la modernidad representada por la moda, los objetos de lujo y los inventos del capitalismo en desarrollo. Con sus vitrinas seductoras y su luz artificial, la galería establece una manera de ver y vivir la realidad, por lo que esta constituye una forma de visualidad que continúa aún hoy en día. Por el contrario, en sus momentos de decadencia, la galería ha sido un refugio para muchos artistas que desafiaron la que se postulaba como la única manera de ver, como Aragon, Breton, Man Ray o Cortázar. 
Hoy en día, la galería sigue siendo un testigo del pasado y de la herencia de las transformaciones sociales y urbanas. Entrando en una galería, no será necesaria más que mirarla con ojos de gato o de infante para comenzar un viaje como el del personaje de Cortázar.

\section{Referencias}

Antoni, J. P. (2009). Lexique de la ville. Paris : Ellipse Éditions Marketing.

Baudelaire, C. (1951). Le Peintre de la vie moderne. Euvres. Paris : Gallimard.

Benjamin, W. (1971). Paris, capitale du XIXe siècle. Euvres II. Poésie et Révolution (pp. 123138). Paris : Denoël.

Benjamin, W. (1982). Charles Baudelaire : un poète lyrique à l'apogée du capitalisme. Paris: Petite bibliothèque Payot.

Benjamin, W. (2003). Paris, capitale du XIXe siècle. Paris: Allia.

Cortázar, J. (1981). Paris : ritmos de una ciudad. Fotografías de Alecio de Andrade. España: Edhasa.

Cortázar, J. (1982). "El otro cielo". En Todos los fuegos el fuego (pp. 135-158). Buenos Aires: Edhasa.

Duval, I. (2014). Les ciel comme passage. Quebéc: Les Herbes rouge.

Fongaro, A. (1988). Quelques images dans Les fleurs du mal. Toulouse: Presse universitaires du Mirail.

Giorgi, A. V. (s. f.). Cidade-luz, cidade-sombra, Interartive. Recuperado de http://interartive. org/2010/07/cidade-luz-cidade-sombra/\#_ftn4

Kennel, S. et al. (2014). Charles Marville : photographer of Paris. National Gallery of Art, Washington. Chicago/Londres: The University of Chicago Press.

Modiano, P. (2014). Discours à l'Académie suédoise. Paris : Gallimard.

Moncan, P. (1993). Les passages en Europe. Paris : Les Éditions du Mécène.

Moncan, P. (1995). Les passages couverts de Paris. Paris : Les Éditions du Mécène.

Perrone-Moisés, L. (2004). Passages : Isidore Ducasse, Walter Benjamin et Julio Cortázar. En Littérature, 136, Montrer n'est pas dire. 
Reffait, C. (2007). La Bourse dans le roman du second XIXe siècle. París: Honoré Champion (coll. Romantisme et modernité 106).

Rimbaud, A. (1992). Cuvres complètes, Correspondance. Paris: Éditions Robert Laffont.

Santiago, S. (2000). O entre-lugar do discurso latino-americano. En Uma literatura nos trópicos: ensaios sobre dependência cultural (2a ed.). Rio de Janeiro: Racco.

Schuwartz, V. R. \& Przyblyski, J. M. (2004). The nineteenth-century visual culture reader. New York/Londres: Routledge.

Simmel, G. (2004). Philosophie de la modernité. Paris: Payot \& Rivages.

Souza, L. R. (2012). Quando Cortázar dialoga com Benjamin: o duplo e o espelho em "Um outro céu" e "Passagens". Recuperado de http://vcoloquiosuldeliteraturacomparada.blogspot. ca/2012/09/comunicacoes.html

Strömberg, P. (2012). L'image de la femme dans quelques poèmes de Charles Baudelaire (Tesis). Université de Lund. Recuperado de http://lup.lub.lu.se/luur/ download? func $=$ downloadFile\&recordOId $=3053993 \&$ fileOId $=305399$ 
Artículos

\section{Anexo}

Imagen de las las galerías cubiertas desaparecidas y existentes en los distritos de Paris donde se desarrolla la novela de Cortázar.

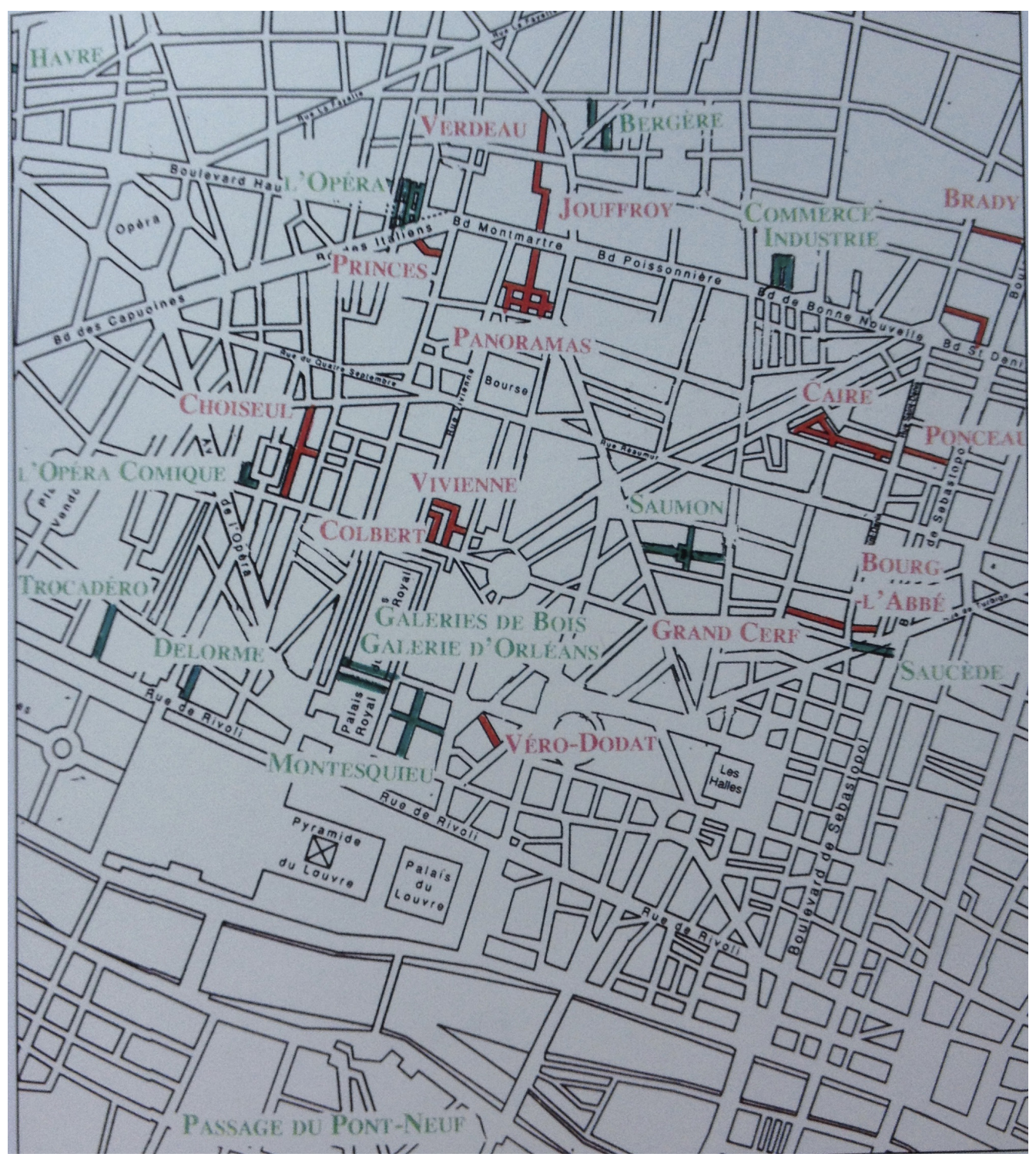

Fuente : Patrice de Moncan, Les passages couverts de Paris, Paris, Les Éditions du Mécène, 1995, p. 89. 